\title{
Motivasi Kerja Karyawan LPP RRI Mataram Dan Pengaruhnya Terhadap Kinerja
}

\author{
Irwan Cahyadi \\ Program Studi Manajemen Universitas Bumigora \\ Email : irwancahyadi@universitasbumigora.ac.id
}

\begin{abstract}
Abstrak
Motivasi merupakan kondisi yang memberikan dorongan kepada manusia untuk melakukan sesuatu demi mencapai tujuan tertentu. Pada dasarnya, setiap manusia membutuhkan motivasi yang menjadi penggerak untuk dapat mengerahkan kemauan dan kemampuannya dalam menyelesaikan suatu pekerjaan dengan sebaik mungkin. Semakin kuat motivasi yang dimiliki oleh seseorang, maka semakin kuat pula usaha yang dikeluarkan untuk menyelesaikan suatu pekerjaan dengan baik. Penelitian ini bertujuan untuk menganalisis factor pembentuk motivasi karyawan LPP RRI Mataram dan pengaruhnya terhadap kinerja, serta melihat factor pembentuk motivasi apa yang paling dominan dalam mempengaruhi kinerja karyawan LPP RRI Mataram. Data dikumpulkan dengan menggunakan kuesioner yang disebarkan kepada 49 orang karyawan LPP RRI Mataram, yang selanjutnya dianalisa dengan menggunakan Analisis Regresi Berganda.

Temuan penelitian ini menunjukkan bahwa dari kelima factor pembentuk motivasi kerja karyawan LPP RRI Mataram yang terdiri dari gaji, keamanan kerja, lingkungan social, penghargaan, dan aktualisasi diri, hanya variable gaji yang memiliki pengaruh signifikan terhadap kinerja karyawan. Sedangkan keempat variable lainnya, yaitu keamanan kerja, lingkungan social, penghargaan, dan aktualisasi diri tetap memiliki pengaruh namun tidak signifikan.
\end{abstract}

Kata kunci : motivasi kerja, gaji, keamanan kerja, lingkungan social, penghargaan, aktuslisasi diri, kinerja 


\section{Pendahuluan}

Setiap organisasi membutuhkan sumber daya manusia dalam upaya mencapai tujuannya karena sumber daya manusia merupakan faktor produksi penting dalam menunjang pelaksanaan kegiatan organisasi. Sumber daya manusia merupakan individu yang unik karena memiliki karakteristik tersendiri dalam bekerja dan memiliki motivasi yang berbeda-beda dalam melaksanakan pekerjaannya yang berujung pada tujuan organisasi. Sumber daya manusia merupakan individu yang unik karena memiliki karakteristik tersendiri dalam bekerja dan memiliki motivasi yang berbeda-beda dalam melaksanakan pekerjaannya yang berujung pada tujuan organisasi. Secara umum, motivasi positif yang dimiliki karyawan akan mendorong karyawan tersebut pada pengerahan kemauan dan kemampuan untuk mengoptimalkan diri pada pekerjaan tersebut. Motivasi adalah suatu keahlian dalam mengarahkan karyawan dan organisasi agar mau bekerja secara berhasil, sehingga keinginan para karyawan dan tujuan organisasi sekaligus tercapai (Flippo dalam $P$. Hasibuan, 2001). Adapun faktor-faktor motivasi berdasarkan teori hirarki kebutuhan dari Maslow (1943) adalah sebagai berikut :

1) Kebutuhan Fisiologis, yaitu kebutuhan makan, minum, perlindungan fisik, seksual, sebagai kebutuhan terendah.

2) Kebutuhan Rasa Aman, yaitu kebutuhan rasa aman dari kehilangan pekerjaan, kebutuhan perlindungan dari ancaman, bahaya, pertentangan dan lingkungan hidup.

3) Kebutuhan Sosial, yaitu kebutuhan untuk diterima dalam kelompok, berafiliasi, dan kebutuhan mencintai dan dicintai

4) Kebutuhan Penghargaan Diri, yaitu kebutuhan akan harga diri, kebutuhan dihormati dan dihargai orang lain.

5) Kebutuhan Aktualisasi Diri, yaitu kebutuhan utnuk menggunakan kemampuan, skill, potensi, kebutuhan untuk berpendapat dengan mengemukakan ide-ide, memberikan penilaian dan kritik terhadap sesuatu.

Robbins (2006) menyatakan bahwa kinerja karyawan adalah sebagai fungsi dari interaksi antara kemampuan dan motivasi, yaitu kinerja= $\mathrm{f}(\mathrm{AxM})$. Bernadin John dan Russel (2010) menyebutkan indikator-indikator kinerja antara lain:

1) Kualitas yaitu tingkat di mana hasil aktivitas yang dilakukan mendekati sempurna

2) Kuantitas yaitu jumlah yang dihasilkan yang dinyatakan dalam istilah atau satuan.

3) Ketepatan waktu yaitu tingkat suatu aktivitas diselesaikan dari yang ditetapkan.

4) Efektivitas yaitu tingkat penggunaan sumber daya organisasi dimaksimalkan guna mencapai tujuan organisasi. 
Orientasi pelanggan atas konsumsi jasa tidak sama dengan pelanggan yang mengkonsumsi produk. Pelanggan yang mengkonsumsi produk, masih menganggap jasa pelayanan sebagai nilai pendukung atas produk yang dikonsumsi. Berbeda halnya dengan pelanggan yang murni mengkonsumsi jasa, nilai yang dirasakan oleh pelanggan terpusat pada pelayanan yang diberikan. Oleh karena itu, sangat penting untuk dapat terus mengoptimalkan motivasi dan kemampuan para karyawan pada perusahaan atau organisasi jasa. Perusahaan dituntun untuk dapat menerapkan kebijakan yang membuat karyawan merasa termotivasi dalam meningkatkan kinerja mereka. Permasalahan yang kerap kali ditemukan dalam rangka peningkatan motivasi kerja adalah perbedaan kebutuhan yang menjadi motif bekerja para karyawan. Oleh sebab itu, sangat menarik untuk mengkaji bagaimana perbedaan motif bekerja para karyawan yang memberikan pelayanan jasa, dalam upaya peningkatan kinerja karyawan melalui kebijakan-kebijakan yang diterapkan secara umum atas seluruh karyawan.

Penelitian ini dilakukan pada Lembaga Penyiaran Publik RRI Regional Mataram yang merupakan lembaga pemberitaan publik yang berdiri sejak tahun 1959 dengan motto "Sekali di udara tetap di Udara". Lembaga yang bergerak dalam bidang Penyiaran dan Pemberitaan dengan tiga bidang siaran yaitu Pro 1 untuk ragam musik dan informasi, Pro 2 untuk gaya hidup dan Pro 3 untuk jaringan berita nasional ini memiliki kantor di jalan Langko nomor 83 Ampenan. Sebagai lembaga penyiaran publik milik negara, LPP RRI Mataram dituntut memberikan peran positifnya dalam pembentukan kehidupan masyarakat yang lebih baik, hal ini diwujudkan dalam program-program yang edukatif dan objektif dalam pemberitaan regional dan nasional juga program yang kompetitif sebagai tuntutan dalam lingkup perusahaan jawatan. Ragam tuntutan profesionalitas ini menjadi salah satu dasar bahwa LPP RRI Mataram membutuhkan sumber daya manusia yang berkompeten untuk mencapai itu semua. Sumber daya yang berkompeten adalah sumber daya yang mampu melaksanakan tugas dan kewajibannya sesuai dengan tujuan pekerjaan tersebut. Guna mendapatkan hasil kerja yang sesuai dengan tujuan deskripsi pekerjaan yang ada melalui kompetensi karyawannya, LPP RRI Mataram telah menerapkan kebijakan baik yang bersifat peraturan pemerintah maupun kebijakan otonomi. Dasar dari kompetensi karyawan adalah spesifikasi pekerjaan atau job person pada saat rekrutmen dan kompetensi berikutnya yang diupayakan adalah melalui upaya memotivasi karyawan dengan salah satu upayanya adalah usaha pemenuhan harapan karyawan. 


\section{Tinjauan Teori}

Pada dasarnya motivasi dapat memacu karyawan untuk bekerja keras sehingga dapat mencapai tujuan mereka. Hal ini akan meningkatkan kinerja karyawan sehingga berpengaruh pada pencapaian tujuan perusahan. Pelaksanaan suatu tugas oleh karyawan akan berjalan dengan baik jika karyawan mempunyai motivasi kerja yang tinggi karena dengan motivasi, karyawan akan mengerahkan kemauan dan kemampuannya untuk menyelesaikan pekerjaannya dengan sebaik mungkin. Hal ini akan berdampak pada penigkatan kinerja baik individu maupun organisasi.

Sebenarnya banyak teoti motivasi yang dikemukakan oleh para ahli manajemen, seperti teori A.H. Maslow, Douglas Mc. Gregor, Frederich Herzberg, atau David Mc Qelland. Salah satu teori motivasi yang banyak mendapat sambutan amat positif di bidang manajemen organisasi adalah "Hierarki Kebutuhan" yang dikemukakan Abraham Maslow. Menurut Maslow, setiap individu memiliki kebutuhan-kebutuhan yang tersusun secara hierarki dari tingkat yang paling mendasar sampai pada tingkatan yang paling tinggi. Setiap kali kebutuhan pada tingkatan paling rendah telah terpenuhi maka akan muncul kebutuhan lain yang lebih tinggi. Pada tingkat yang paling bawah, dicantumkan berbagai kebutuhan dasar yang bersifat biologis. Pada tingkatan yang lebih tinggi dicantumkan berbagai kebutuhan yang bersifat sosial. Pada tingkatan yang paling tinggi dicantumkan kebutuhan untuk mengaktualisasikan diri.



\section{Gambar Hierarki Kebutuhan Maslow}

Gambar di atas menunjukkan tingkat hierarki kebutuhan manusia pada umumnya menurut Abraham Maslow. Kebutuhan yang pertama dan utama adalah kebutuhan fisilogi. Kebutuhan fisiologi merupakan kebutuhan paling dasar yang lebih berhubungan pada kebutuhan fisik, seperti kebutuhan makanan, minuman, tempat berteduh, seks, tidur, dan oksigen. Kebutuhan fisiologi merupakan kebutuhan yang memiliki potensi besar untuk menuju ke tingkat kebutuhan berikutnya. Misalnya, ketika manusia merasa lapar, maka akan mengabaikan atau menekan dulu kebutuhan lain. Manusia akan memuaskan rasa lapar tersebut dengan mencari makanan dan minuman. Untuk manusia yang sudah mapan, sebuah rasa lapar merupakan gaya hidup. Mereka sudah memiliki cukup makanan, tetapi yang mereka rasakan ialah 
citarasa dari makanan yang mereka inginkan. Berbeda dengan manusia yang belum mapan, ketika merasa lapar, mereka tidak mementingkan cita rasa, tekstur, bau, ataupun temperatur.

Setelah manusia mampu memenuhi kebutuhan dasar, yaitu kebutuhan fisiologi, tingkatan selanjutnya yang dibutuhkan manusia adalah rasa aman, seperti rasa aman fisik, stabilitas, ketergantungan, perlindungan, dan kebebasan dari berbagai ancaman, teroris, penyakit, takut, cemas, atau bencana alam. Apabila kebutuan fisiologi perlu dipenuhi secara total, sedangkan kebutuhan akan rasa aman tidak bisa terpenuhi secara total. Manusia tidak bisa dapat terlindungi dari berbagai ancaman meteor, kebanjiran, atau ancaman dari orang lain. Menurut Maslow, orang-orang yang tidak merasa aman mempunyai tingkal laku yang berbeda. Mereka akan bertingkah laku seperti orang yang memiliki ancaman besar. Orang yang merasa tidak aman otomatis akan mencari kestabilan dan akan berusaha keras menghindari hal-hal atau keadaan yang asing atau yang tidak diharapkan.

Setelah dua kebutuhan di atas terpenuhi, selanjutnya akan muncul kebutuhan social, yaitu kebutuhan akan rasa memiliki-dimiliki dan kasih sayang. Manusia akan mencari sahabat, pasangan, keturunan, dan kebutuhan untuk dekat dengan keluarga. Seseorang yang cintanya sudah relatif terpenuhi tidak akan merasa panik ketika menolak cinta dan ketika ada seseorang yang menolak dirinya, ia juga tidak merasa hancur. Maslow berpendapat bahwa kebutuhan cinta merupakan cinta yang memberi dan cinta yang menolak. Kita perlu memahami cinta, mengamalkannya, menciptakannya, dan mengajarkannya. Setelah tiga kebutuhan di atas terpenuhi, manusia akan mengejar kebutuhan akan penghargaan, seperti menghormati orang lain, status, ketenaran, reputasi, perhatian, dan sebagainya. Menurut Maslow, kebutuhan akan penghargaan juga terbagi atas dua tingkatan, yaitu tingkatan yang rendah dan tinggi. Tingkatan rendah yaitu kebutuhan untuk menghormati orang lain, kebutuhan status, ketenaran, reputasi, perhatian, apresiasi, martabat, dan dominasi. Kebutuhan yang tinggi ialah kebutuhan harga diri seperti perasaan, keyakinan, kompetensi, prestasi, penguasaan, kemandirian, dan kebebasan. Maslow berpendapat, apabila kebutuhan harga diri sudah teratasi, maka manusia siap memenuhi kebutuhan pada tingkat yang lebih tinggi lagi.

Kebutuhan pada tingkat tertinggi adalah aktualisasi diri. Kebutuhan aktualisasi diri merupakan tingkatan kebutuhan yang paling tinggi. Kebutuhan ini melibatkan keinginan yang terus-menerus untuk mencapai potensi. Menurut Maslow, kebutuhan ini ialah kebutuhan yang dimiliki manusia untuk melibatkan diri sendiri untuk menjadi apa yang sesuai keinginannya berdasarkan kemampuan diri. Manusia akan memenuhi hasratnya sesuai dengan kemamuan yang dimiliki pada dirinya.

Dengan mengetahui kebutuhan karyawan, perusahaan setidaknya dapat memiliki gambaran tentang motiviasi utama karyawan dalam bekerja. Dengan memberikan rangsangan akan pemenuhan kebutuhan tersebut diharapkan dapat meningkatkan motivasi kerja karyawang yang bersangkutan, yang selanjutnya akan berdampak terhadap peningkatan kinerja kawaryan. Istilah kinerja sebenarnya adalah 
pengalihbahasaan dari kata Inggris "performance" yang mempunyai arti prestasi kerja, pelaksanaan kerja, penyelenggaraan kerja. Keputusan ketua Lembaga Administrasi Negara Republik Indonesia Nomor 589/IX/6/4/99 tanggal 20 September 1999 tentang Pedoman Penyusunan Pelaporan Akuntabilitas Kinerja Instansi Pemerintah (LAKIP) menyatakan bahwa "kinerja adalah gambaran mengenai tingkat pencapaian pelaksanaan suatu kegiatan atau progaram atau kebijakan dalam mewujudkan sasaran, tujuan, misi dan visi organisasi. Secara sederhana kinerja dapat diartikan sebagai hasil yang dicapai oleh seorang karyawan selama periode waktu tertentu pada bidang pekerjaan tertentu. Seorang karyawan yang memiliki kinerja yang tinggi dan baik dapat menunjang tercapainya tujuan dan sasaran yang telah ditetapkan oleh perusahaan. Untuk dapat memiliki kinerja yang tinggi dan baik, seorang karyawan dalam melaksanakan pekerjaannya harus memiliki keahlian dan keterampilan sesuai dengan pekerjaan yang dimiliki yang didukung dengan motivasi kerja yang tinggi.

Penilaian kinerja merupakan suatu proses organisasi dalam menilai unjuk kerja pegawainya. Tujuan dari penilaian kinerja secara umum adalah memberikan feedback kepada pegawai dalam upaya memperbaiki tampilan kerjanya dan upaya meningkatkan produktivitas organisasi dan secara khusus dilakuakan dalam kaitannya dengan berbagai kebijaksanaan terhadap pegawai serta untuk tujuan promosi, kenaikan gaji, pendidikan dan latihan. Bernadin John dan Russel (2010) menyatakan bahwa indikator-indikator kinerja antara lain: 1) Kualitas, yaitu tingkat di mana hasil aktivitas yang dilakukan mendekati sempurna ,2) Kuantitas, yaitu jumlah yang dihasilkan yang dinyatakan dalam istilah atau satuan, 3) Ketepatan waktu, yaitu tingkat suatu aktivitas diselesaikan dari yang ditetapkan, dan 4) Efektivitas, yaitu tingkat penggunaan sumber daya organisasi dimaksimalkan guna mencapai tujuan organisasi. Malayu S.P Hasibuan (2001) menyatakan bahwa "Kinerja adalah suatu hasil karya yang dicapai seseorang dalam melaksanakan tugas-tugas yang dibebankan kepadanya yang didasarkan atas kecakapan, pengalaman dan kesungguhan serta waktu. Prestasi kerja ini adalah gabungan dari 3 faktor penting yaitu kemampuan dan minat seorang pekerja, kemampuan dan penerimaan atas penjelasan delegasi tugas dan peran serta motivasi seorang pekerja. 


\section{Kerangka Kosneptual}

Berdasarkan tinjauan penelitian terdahulu dan kajian teori yang telah dibahas sebelumnya, maka dapat disusun kerangka konseptual penelitian yang menggambarkan mengenai pengaruh factor-faktor motivasi terhadap kinerja karyawan adalah sebagai berikut :

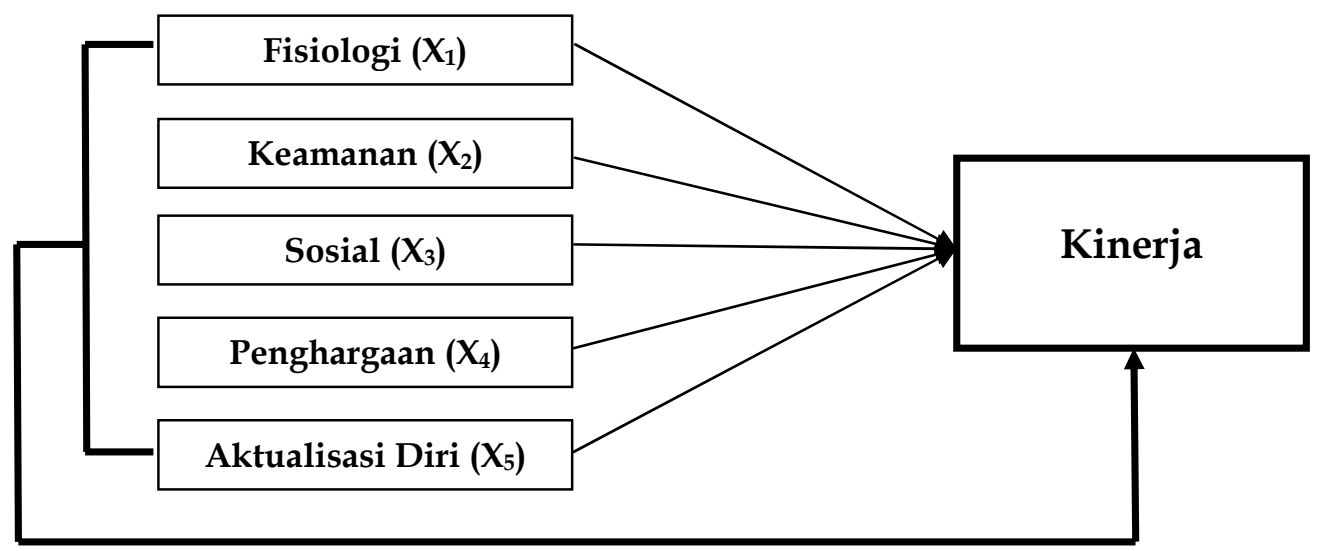

\section{Gambar Kerangka Konseptual Penelitian}

\section{Metode Penelitian}

Jenis penelitian yang digunakan dalam penelitian ini adalah penelitian asosiatif, yaitu mencari hubungan faktor-faktor motivasi seperti pemenuhan kebutuhan dasar (fisiologi), pemenuhan kebutuhan akan rasa aman, pemebnuhan kebutuhan sosial, penghargaan dan aktualisasi diri terhadap kinerja karyawan pada LPP RRI Mataram. Penelitian ini mengambil pegawai LPP RRI Mataram sebagai populasi penelitian yaitu sebanyak 95 orang pegawai. Sementara untuk penentuan jumlah sampel penelitian, digunakan rumus Slovin, di mana jumlah sampel yang digunakan dalam penelitian ini adalah sebanyak 49 orang pegawai. Selanjutnya dalam menentukan sampel, digunakan metode simpel random sampling yaitu sampel yang diambil sedemikian rupa sehingga setiap unsur atau setiap orang dalam populasi memiliki kesempatan sama untuk terpilih sebagai anggota sampel.

Alat pengumpulan data yang digunakan adalah kuesioner, di mana kuesioner tersebut bersumber dari beberapa penelitian terdahulu disesuaikan dengan teori yang digunakan dalam penelitian ini serta dikembangkan sesuai dengan kebutuhan, situasi dan kondisi pada lokasi penelitian. Selanjutnya untuk mengukur kinerja pegawai, kueioner diberikan kepada atasan langsung, yaitu Kepala LPP RRI Mataram untuk mendapatkan jawaban yang lebih objektif. Hasil yang diperoleh dari jawaban responden atas kuesioner yang diberikan kemudian diolah dengan menggunakan alat analisis regresi linier berganda. Alat analisis ini digunakan untuk dapat mengetahui pengaruh masing-masing factor-faktor motivasi terhadap kinerja pegawai LPP RRI Mataram, baik secara parsial maupun simultan, serta untuk melihat factor motivasi apa yang memiliki pengaruh yang paling dominan. 


\section{Analisis Data dan Diskusi}

\subsection{Analisis Data}

Penelitian ini menggunakan pendapat 53 orang pegawai yang bekerja pada LPP RRI Mataram selama periode penelitian. Hasil pengisian kuesioner menunjukkan terdapat beberapa karakteristik responden antara lain, berdasarkan pada jenis kelamin, pendidikan terakhir, dan jabatan. Uraian tentang karakteristik responden penelitian dapat dilihat pada tabel berikut :

Tabel 1.

Distribusi Karakteristik Responden Penelitian

\begin{tabular}{cllcc}
\hline $\begin{array}{c}\text { No } \\
.\end{array}$ & Identitas Diri & Distribusi Responden & $\begin{array}{c}\text { Jumlah } \\
\text { (orang) }\end{array}$ & $\begin{array}{c}\text { Persentase } \\
\text { (\%) }\end{array}$ \\
\hline 1. & Jenis Kelamin & Laki-laki & 72 & 75,79 \\
& & Perempuan & 23 & 24,21 \\
2. & Pendidikan & S2 & 1 & 1,05 \\
& & S1 / D4 & 41 & 44,28 \\
& D3 & 4 & 5,33 \\
& D2 & 1 & 1,05 \\
& D1 & 3 & 3,16 \\
& SMA & 43 & 45,26 \\
3. Jabatan & SLTP & 2 & 2,10 \\
& & Kepala LPP RRI & 1 & 1,05 \\
& & Kasubbag & 4 & 5,33 \\
& & Kepala Seksi & 4 & 5,33 \\
& & Kasub Seksi & 12 & 12,63 \\
& & Staf & 74 & 75,66 \\
\hline
\end{tabular}

Sumber : Data Primer Diolah

Berdasarkan jenis kelamin, sebagian besar pegawai berjenis kelamin laki-laki, yaitu 72 orang $(75,79 \%)$, dan pegawai yang berjenis kelamin perempuan sebanyak 23 orang $(24,21 \%)$. Berdasarkan tingkat pendidikan, pegawai LPP RRI Mataram didominasi oleh pegawai dengan tingkat pendidikan SMA dan S1/D4, yaitu sebanyak 43 orang $(45,26 \%)$ untuk pegawai dengan tingkat pendidikan SMA, dan sebanyak 41 orang $(44,28 \%)$ untuk pegawai dengan tingkat pendidikan S1/D4. Dan berdasarkan jabatan didominasi oleh pegawai yang menempati posisi staf, yaitu sebanyak 74 orang $(75,66 \%)$. Selanjutnya akan dipaparkan gambaran atas jawaban responden terhadap kuesioner yang telah diberikan. Terdapat 5 (lima) faktor motivasi yang menjadi variable bebas dalam penelitian ini, yaitu kebtuhan fisiologi, keamanan, social, penghargaan, dan aktualisasi diri. Dalam penerapan kondisi nyata tersebut di atas dibagi dalam 5 (lima) tingkatan kondisi, yaitu sangat puas, puas, cukup puas, rendah, dan sangat rendah. Sedangkan untuk variable terikat, yaitu kinerja karyawan menggunakan 6 (enam) indicator dengan 5 (lima) tingkatan kondisi, yaitu sangat tinggi, tinggi, cukup tinggi, rendah, dan sangat rendah, adapun analisanya dapat dilihat pada tabel di bawah ini. 
Tabel 2.

Kriteria Jawaban Responden Penelitian

\begin{tabular}{|c|c|c|}
\hline No & Variabel & Kriteria \\
\hline 1 & Fisiologi $\left(X_{1}\right)$ & Puas \\
\hline 2 & $\operatorname{Kemanan}\left(\mathrm{X}_{2}\right)$ & Puas \\
\hline 3 & Sosial $\left(X_{3}\right)$ & Sangat Puas \\
\hline 4 & Penghargaan $\left(\mathrm{X}_{4}\right)$ & Puas \\
\hline 5 & $\begin{array}{c}\text { Aktualisasi Diri } \\
\left(X_{5}\right)\end{array}$ & Puas \\
\hline 6 & Kinerja $(\mathrm{Y})$ & Tinggi \\
\hline
\end{tabular}

Tabel 2 di atas menggambarkan distribusi jawaban 49 orang responden terhadap kuesioner yang diajukan atas 5 (lima) variable bebas, yaitu kebutuhan fisiologi, keamanan, social, penghargaan, dan aktualisasi diri, serta variable kinerja pegawai menjadi variable terikat. Dari kelima variable bebas tersebut, 4 (empat) diantaranya memiliki criteria tinggi, yaitu variable kebutuhan fisiologi, keamanan, penghargaan dan aktualisasi diri. Variabel social memiliki criteria yang paling tinggi, yaitu sangat tinggi. Hal ini mendadakan bahwa pegawai LPP RRI Mataram sudah merasa puas atas kelima factor motivasi yang diberikan oleh perusahaan. Selain itu, hal ini juga menandakan bahwa kelima variable tersebut dapat diterima dengan baik oleh para pegawai LPP RRI Mataram sebagai factor yang dapat meningkatkan motivasi karyawan pada LPP RRI Mataram. Selanjutnya variable terikat yaitu kinerja karyawan memiliki criteria tinggi. Hal ini menunjukkan bahwa hasil pekerjaan para pegawai LPP RRI Mataram dilihat dari 6 (enam) indicator yang diajukan sudah menunjukkan kinerja yang baik.

Selanjutnya akan dijelaskan pengaruh antara variable bebas, yaitu factor-faktor motivasi terhadap variable terikat, yaitu kinerja karyawan berdasarkan hasil pengolahan data dengan menggunakan analisis regresi linier berganda.

1) Analisis Regresi Berganda

Berdasarkan pengujian analisis regresi berganda yang dilakukan dengan bantuan program SPSS, maka dihasilkan persamaan regresei sebagai berikut :

$$
Y=0,105+0,869 \text { X1 + 0,118 X2 + 0,146 X3 + 0, 066 X4 - 0,419 X5 }
$$

Persamaan regresi di atas menunjukkan bahwa variabel bebas: kebutuhan fisiologi $\left(X_{1}\right)$, keamanan $\left(X_{2}\right)$, sosial $\left(X_{3}\right)$, dan penghargaan $\left(X_{4}\right)$ mempunyai koefisien regresi bertanda positif. Ini berarti bahwa jika keempat variabel bebas tersebut mengalami peningkatan maka akan menyebabkan peningkatan pula (dampak positif) pada kinerja karyawan LPP RRI Mataram. Dan begitu juga sebaliknya, jika keempat variabel tersebut mengalami penurunan maka akan menyebabkan penurunan pula pada kinerka karyawan LPP RRI Mataram. Sedangkan variabel aktualisasi diri $\left(\mathrm{X}_{5}\right)$ mempunyai koefisien regresi bertanda 
negative, artinya adalah jika variabel aktualisasi diri mengalami peningkatan maka akan menyebabkan penurunan (berdampak negatif) pada kinerja karyawan LPP RRI Mataram. Sebaliknya jika variabel aktualisasi diri turun maka akan meningkatkan kinerja karyawan LPP RRI Mataram.

2) Analisis Determinasi Berganda $\left(R^{2}\right)$

Analisis determinasi adalah analisis yang digunakan untuk mengukur kontribusi variabel bebas yaitu factor-faktor motivasi kerja yang terdiri atas kebutuhan dasar $\left(X_{1}\right)$, keamanan $\left(X_{2}\right)$, sosial $\left(X_{3}\right)$, penghargaan $\left(X_{4}\right)$, dan aktualisasi diri $\left(\mathrm{X}_{5}\right)$ terhadap variable terikat yaitu kinerja karyawan $(\mathrm{Y})$ pada LPP RRI Mataram. Berdasarkan hasil analisa determinasi berganda, diperoleh $R^{2}$ sebesar 0,616 atau 61,6\% yang berarti bahwa variabel bebas yang terdiri dari kebutuhan dasar $\left(X_{1}\right)$, keamanan $\left(X_{2}\right)$, sosial $\left(X_{3}\right)$, penghargaan $\left(X_{4}\right)$, dan aktualisasi diri $\left(X_{5}\right)$ memberikan kontribusi sebesar $61,6 \%$ terhadap variabel terikat yaitu kinerja karyawan (Y) pada LPP RRI Mataram, sedangkan sisanya sebesar $38,4 \%$ merupakan kontribusi dari variabel lain yang tidak diamati dalam penelitian ini.

3) Pengujian Hipotesis

a. Uji F atau Uji Hipotesis Pertama

Pengujian ini digunakan untuk mengetahui pengaruh faktor-faktor motivasi kerja (kebutuhan fisiologi, keamanan, social, pengahrgaan, dan aktualisasi diri) terhadap kinerja karyawan secara serentak atau bersama-sama. Berdasarkan pengujian yang telah dilakukan, koefisien regresi secara serentak menunjukkan adanya pengaruh yang nyata (signifikan) antara variabel bebas (kebutuhan fisiologi, keamanan, social, pengahrgaan, dan aktualisasi diri) terhadap variabel terikat (kinera karyawan), yang ditunjukkan oleh nilai $f_{\text {hitung }}$ lebih besar dari $f_{\text {tabel }}$ yaitu 9,182 $>2,43$. Dengan demikian maka $\mathrm{H}_{0}$ ditolak yang berarti bahwa terdapat pengaruh yang nyata (signifikan) antara antara variabel bebas (kebutuhan fisiologi, keamanan, social, pengahrgaan, dan aktualisasi diri) terhadap variabel terikat (kinera karyawan).

b. Uji t atau Uji Hipotesis Kedua

Pengujian ini digunakan untuk melihat signifikansi pengaruh antara variabel bebas yaitu factor-faktor motivasi kerja yang terdiri dari kebutuhan fisiologi $\left(\mathrm{X}_{1}\right)$, keamanan $\left(\mathrm{X}_{2}\right)$, sosial $\left(\mathrm{X}_{3}\right)$, penghargaan $\left(\mathrm{X}_{4}\right)$, dan aktualisasi diri $\left(X_{5}\right)$ secara parsial (sendiri-sendiri) terhadap variable terikat yaitu kinerja karyawan (Y) pada LPP RRI Mataram. Berdasarkan hasil pengujian yang telah dilakukan maka diperoleh hasil sebagai berikut :

a) Dari hasil perhitungan data diperoleh hasil bahwa thitung untuk variabel kebutuhan fisiologi sebesar 4,537 dengan nilai signifikansi 0,000. Apabila thitung tersebut dibandingkan dengan tabel sebesar 2,00, maka nilai thitung tersebut lebih besar dari tabel yang berarti $\mathrm{H}_{0}$ ditolak (Ha diterima). Hal ini juga dapat dilihat dari perbandingan antara nilai signifikansi sebesar 
0,000 yang berarti probabilitas kesalahan lebih kecil dari 0,05 atau 5\%. Dengan demikian, bila $\mathrm{H}_{0}$ ditolak artinya variabel kebutuhan dasar mempunyai pengaruh yang signifikan terhadap kinerja karyawan.

b) Hasil thitung untuk variabel keamanan sebesar .400 dengan nilai signifikansi 0,69. Apabila thitung tersebut dibandingkan dengan tabel sebesar 2,00, maka nilai thitung tersebut lebih kecil dari tabel yang berarti $\mathrm{H}_{0}$ diterima (Ha ditolak). Hal ini juga dapat dilihat dari perbandingan antara nilai signifikansi sebesar 0,69 yang berarti probabilitas kesalahan lebih besar dari 0,05 atau 5\%. Dengan demikian bila $\mathrm{H}_{0}$ diterima artinya variabel keamanan pekerjaan mempunyai pengaruh yang tidak signifikan terhadap kinerja karyawan.

c) Hasil thitung untuk variabel kebutuhan sosial sebesar .697 dengan nilai signifikansi 0,49. Apabila thitung tersebut dibandingkan dengan $t_{\text {tabel }}$ sebesar 2,00, maka nilai thitung tersebut lebih kecil dari tabel yang berarti $\mathrm{H}_{0}$ diterima (Ha ditolak). Hal ini juga dapat dilihat dari perbandingan antara nilai signifikansi sebesar 0,49 yang berarti probabilitas kesalahan lebih besar dari 0,05 atau $5 \%$. Dengan demikian bila $\mathrm{H}_{0}$ diterima artinya variabel sosial mempunyai pengaruh yang tidak signifikan terhadap kinerja karyawan.

d) Hasil thitung untuk variabel penghargaan sebesar .208 dengan nilai signifikansi 0,83. apabila $t_{\text {hitung }}$ tersebut dibandingkan dengan $t_{\text {tabel }}$ sebesar 2,00, maka nilai thitung tersebut lebih kecil dari tabel yang berarti $\mathrm{H}_{0}$ diterima (Ha ditolak). Hal ini juga dapat dilihat dari perbandingan antara nilai signifikansi sebesar 0,83 yang berarti probabilitas kesalahan lebih besar dari 0,05 atau $5 \%$. Dengan demikian bila $\mathrm{H}_{0}$ diterima artinya variabel penghargaan mempunyai pengaruh yang tidak signifikan terhadap kinerja karyawan.

e) Variabel aktualisasi diri bernilai negatif yaitu sebesar -1,573 yang bermakna bahwa variabe ini memiliki pengaruh yang berbanding terbalik dengan kinerja karyawan. Artinya bahwa jika aktualisasi diri karyawan ditingkatkan maka kinerja karyawan akan turun. Jadi signifikansi pengaruh variabel aktualisasi diri terhadap kinerja karyawan tidak perlu untuk dinilai lagi.

4) Uji Asumsi Klasik atau Pengujian Model

Pengujian ini dilakukan untuk mengetahui validitas dari model analisis data yang digunakan yaitu regresi linier berganda sebagai alat penduga dalam mengetahui pengaruh antara variable bebas terhadap variable terikat. Berikut dipaparkan hasi atas pengujian tersebut:

a. Uji Normalitas Data

Asumsi normalitas bertujuan untuk menguji apakah dalam sebuah model regresi, variable terikat, variable bebas, atau keduanya mempunyai distribusi normal atau tidak. Model regresi yang baik adalah distribusi data 
normal atau mendekati normal, dan dari pengujian yang telah dilakukan dapat diketahui bahwa data pada model yang digunakan terdistribusi normal, karena data menyebar disekitar garis diagonal dan mengikuti arah garis diagonal sehingga dapat dinyatakan bahwa model regresi memenuhi asumsi normalitas.

b. Uji Autokorelasi

Asumsi autokorelasi bertujuan untuk mengetahui ada tidaknya korelasi pada serangkaian residual dalam model yang digunakan. Dan untuk mendeteksi hal tersebut, maka digunakan uji statistic Durbin-Watson, di mana berdasarkan pengujian yang telah dilakukan dapat diketahui bahwa tidak terdapat autokorelasi pada model yang digunakan, sehingga asumsi autokorelasi dapat terpenuhi.

c. Uji Heteroskedastisitas

Asumsi heteroskedastisitas bertujuan untuk mengetahui apakah dalam model yang digunakan terjadi ketidaksamaan variasi dari nilai residual antara pengamatan yang satu dengan yang lain. Untuk memenuhi asumsi tersebut, maka model yang digunakan tidak memiliki gejala heteroskedastisitas, dan berdasarkan pengujian yang telah dilakukan dapat diketahui bahwa model yang digunakan tidak memiliki gejala heteroskedastisitas, sehingga asumsi heteroskedastisitas dapat terpenuhi pada model yang digunakan.

d. Uji Multikolinearitas

Analisis multikolinieritas bertujuan untuk menguji apakah di dalam model regresi ditemukan adanya korelasi antar variable bebas, jika terjadi korelasi, maka disebut terdapat problem multikolinieritas (multiko). Model regresi yang baik seharusnya tidak terjadi korelasi diantara variable bebas, dan berdasarkan pengujian yang telah dilakukan terhadap model regresi yang digunakan dapat diketahui bahwa model regresi tersebut tidak memiliki masalah multikolinearitas.

\subsection{Diskusi}

Pada sub bab ini akan dibahas hasil perhitungan yang telah dilakukan. Penelitian ini bertujuan untuk mengetahui pengaruh factor-faktor motivasi yang terdiri atas kebutuhan fisiologi, keamanan, social, penghargaan dan aktualisasi diri terhadap kinerja karyawan pada LPP RRI Mataram. Berdasarkan hasil analisis regresi linier berganda, maka diperoleh persamaan regresi sebagai berikut :

$$
\mathrm{Y}=0,105+0,869 \mathrm{X} 1+0,118 \mathrm{X} 2+0,146 \mathrm{X3}+0,066 \mathrm{X} 4+- \text { 0,419 X5 }
$$

Dapat ditarik kesimpulan bahwa variabel $X_{1}, X_{2}, X_{3}$, dan $X_{4}$ mempunyai arah hubungan positif terhadap kinreja karywan. Artinya apabila terjadi perubahan pada variabel $X_{1}, X_{2}, X_{3}$, dan $X_{4}$ maka akan membawa pengaruh pada peningkatan kinerja karyawan. Sedangkan $X_{5}$ bernilai negative, artinya adalah jika variabel aktualisasi diri mengalami peningkatan maka akan menyebabkan penurunan 
(berdampak negatif) pada kinerja karyawan. Hal ini dapat terjadi karena responden penelitian adalah karyawan dengan spesifikasi staf yang apabila dihubungkan dengan dasar teori yang digunakan yaitu teori Hierarki Kebutuhan Maslow maka responden dengan spesifikasi staf memiliki kecenderungan untuk belum siap terhadap tingkatan aktualisasi diri, di mana teori Maslow menjelaskan dengan model piramida terbaliknya bahwa setiap kebutuhan akan meningkat jika kebutuhan dibawahnya telah terpenuhi. Jadi kesimpulannya adalah $X_{5}$ bernilai negatif karena karyawan responden masih berada pada tingkatan $X_{1}$ sampai dengan $\mathrm{X}_{4}$ atau kebutuhan dasar sampai dengan penghargaan. Berikut akan dipaparkan hasil yang dapat dirangkum berdasarkan hasil analisis data yang telah dilakukan.

1) Dari hasil tebel frekuensi skor jawaban, dapat disimpulkan bahwa responden menilai bahwa faktor-faktor motivasi (kebutuhan fisiologi, keamanan, sosial, pujian dan penghargaan, dan aktualisasi diri) secara umum termasuk dalam kategori sangat tinggi dan tinggi. Begitu juga dengan kinerja karyawan pada LPP RRI Mataram dapat dikatakan tergolong baik.

2) Berdasarkan perhitungan regresi linier berganda menunjukkan bahwa dari kelima variabel bebas yang diteliti ternyata empat diantaranya yaitu $X_{1}, X_{2}$, $\mathrm{X}_{3}$, dan $\mathrm{X}_{4}$ berpengaruh signifikan terhadap kinerja karyawan sedangkan $\mathrm{X}_{5}$ memiliki pengaruh berbanding terbalik.

3) Berdasarkan hasil analisa determinasi berganda diperoleh $R^{2}$ sebesar 0,62 atau $62 \%$ yang berarti bahwa variabel kebutuhan fisiologi, keamanan, sosial, pujian dan penghargaan, dan aktualisasi diri memberikan kontribusi sebesar $62 \%$ terhadap kinerja karyawan pada LPP RRI Mataram, sedangkan sisanya sebesar $38 \%$ merupakan kontribusi dari variabel lain yang tidak diamati.

4) Berdasarkan uji kemaknaan koefisien regresi secara serentak menunjukkan adanya pengaruh yang nyata (signifikan) antara variabel bebas terhadap variabel terikat, yang ditunjukkan oleh $\mathrm{f}_{\text {hitung }}$ lebih besar dari $\mathrm{f}_{\text {tabel }}$ yaitu 9,182 > 2,430 maka $\mathrm{H}_{0}$ ditolak yang berarti bahwa terdapat pengaruh yang signifikan antara variabel bebas terhadap variabel terikat.

5) Variabel bebas $(X)$ yang paling dominan berpengaruh terhadap kinerja karyawan LPP RRI Mataram adalah kebutuhan dasar. Hal ini dapat dilihat dari jawaban masing-masing responden pada questioner di mana responden rata-rata menjawab sangat setuju. Sedangkan variabel bebas (X) yang paling tidak berpengaruh adalah aktualisasi diri, hal ini dapat dilihat dari jawaban masingmasing respoden questioner yang menghasilkan nilai negatif pada pengujian SPSS. Jadi karyawan LPP RRI Mataram lebih termotivasi dalam bekerja dan meningkatkan kinerja melaui sesuatu yang lebih bersifat materi dari pada non materi.

6) Pengujian hipotesis melalui uji t menunjukkan bahwa secara parsial, variabel $X_{2}$, $\mathrm{X}_{3}$, dan $\mathrm{X}_{4}$ atau keamanan, sosial, dan penghargaan memiliki pengaruh positif terhadap kinerja karyawan tetapi dari hasi penelitian pada Responden LPP RRI 
Mataram, didapatkan hasil bahwa pengaruh yang diberikan oleh ketiga variabel tersebut tidak signifikan. Hal ini kemungkinan bisa terjadi karena pola penerapan yang belum efektif.

\section{Kesimpulan dan Rekomendasi}

Berdasarkan hasil penelitian pada karyawan LPP RRI Mataram, maka dapat disampaikan beberapa hal, yaitu kebutuhan fisiologis berpengaruh signifikan dan positif terhadap kinerja karyawan LPP RRI Mataram. Hal ini menunjukkan bahwa semakin baik dan meningkat pemeuhan atas kebutuhan fisiolgis yang dirasakan oleh karyawan LPP RRI Mataram, maka kinerja karyawan LPP RRI Mataram akan meningkat. Begitu pula sebaliknya, jika pemenuhan atas kebutuhan fisiologis yang dirasakan oleh karyawan LPP RRI Mataram tidak baik dan rendah, maka kinerja karyawan LPP RRI Mataram akan menurun. Kebutuhan akan rasa aman berpengaruh positif namun tidak signifikan terhadap kinerja karyawan LPP RRI Mataram. Hal ini berarti tingkat peningkatan kinerja karyawan LPP RRI Mataram yang disebabkan oleh terpenuhinya kebutuhan akan rasa aman rendah. Begitu juga sebaliknya, pemenuhan akan kebutuhan rasa aman yang dirasakan oleh karyawan LPP RRI Mataram tidak baik atau rendah, maka hal tersebut tidak akan mengganggu kinerja karyawan LPP RRI Mataram. Pemenuhan atas kebutuan social juga dirasakan tidak begitu penting oleh karyawan LPP RRI Mataram. Hasil penelitian menunjukkan kebutuhan social beroengaruh positif namun tidak signifikan terhadap kinerja karyawan LPP RRI Mataram. Peningkatan kinerja sebagai hasil atas pemenuhan kebutuhan social yang dirasakan oleh karyawan LPP RRI Mataram tidak banyak. Begitu juga sebaliknya, pemenuhan atas kebutuhan social yang tidak baik atau rendah tidak akan mengganggu kinerja karyawan LPP RRI Mataram. Kebutuhan akan penghargaan juga dinilai tidak penting oleh karyawan LPP RRI Mataram. Hasil penelitian menunjukkan bahwa kebutuhan akan penghargaan berpengaruh positif namun tidak signifikan terhadap kinerja karyawan LPP RRI Mataram. Hal ini menunjukkan bahwa pemberian penghargaan kepada karyawan LPP RRI Mataram hanya memberikan dampak yang kecil terhadap peningkatan kinerja karyawan LPP RRI Mataram. Begitu juga sebaliknya, tidak adanya penghargaan yang diberikan kepada karyawan LPP RRI Mataram tidak akan mengganggu kinerja mereka. Untuk aktualisasi diri, penelitian menunjukkan bahwa aktualisasi diri memiliki pengaruh negative atau berbanding terbalik terhadap kinerja karyawan LPP RRI Mataram. Hal ini menunjukkan bahwa semakin tinggi aktualisasi diri yang diberikan kepada karyawan LPP RRI Mataram akan menurunkan kinerja mereka. Begitu juga sebaliknya, semakin rendah aktualisasi yang diberikan kepada karyawan LPP RRI Mataram akan meningkatkan kinerja mereka.

Untuk mempertahankan kinerja karyawan LPP RRI Mataram, pihak manajemen sebaiknya memperhatikan factor apa yang dianggap penting dalam meningkatkan motivasi oleh karyawan LPP RRI Mataram. Seperti yang ditunjukkan oleh hasil penelitian, di mana kebutuhan fisiologis merupakan factor motivasi yang paling 
signifikan dalam meningkatkan kinerja karyawan LPP RRI Mataram. Kebutuhan fisiologis ini berkaitan dengan penggajian, tunjangan, dan fasilitas yang diberikan oleh perusahaan. Dengan terpenuhinya kebutuhan fisiologis dengan baik, maka diharapkan dapat meningkatkan motivasi karyawan LPP RRI Mataram sehingga akan berdampak terhadap meningkatnya kinerja mereka.

\section{Daftar Pustaka}

Abidin, A., 2004, Analisis Pengaruh Faktor-Faktor Motivasi Terhadap Prestasi Kerja Pegawai Dinas Peternakan Provinsi Nusa Tenggara Barat, Universitas Mataram : Mataram.

Adisoewignyo, W., 2007, Statistik Inferensi Ekonomi Dan Bisnis, Mataram University Press : Mataram.

Bernardin, H.J., Russel, 2010, Human Resource Management, McGraw-Hill : New York. Hasibuan, M.S.P., 2001, Manajemen Sumber Daya Manusia, Edisi Revisi, PT. Bumi Aksara : Jakarta.

Juhanita, I.H., 2008, Analisa Konflik Antar Kepegawaian Dan Pengaruhnya Terhadap Prestasi Kerja Pada Badan Pemberdayaan Masyarakat Pemerintah Provinsi Nusa Tenggara Barat, Universitas Mataram : Mataram

Manulang, M.,. 2006, Manajemen Personalia, Gadjah Mada University Press : Yogyakarta. Mujiburrahman, M., 2007, Analisis Pengaruh Faktor-Faktor Motivasi Terhadap Produktivitas Kerja Karyawan (Kasus Pada Perusahaan KIKY Bakery di Babakan), Universitas Mataram : Mataram.

Nazir, M., 1999, Metode Penelitian, Galia Indonesia : Jakarta

Prawirosentono, S., 1999, Kebijakan Kinerja Karyawan, Edisi Satu, BPFE : Yogyakarta

Rivai, V., 2004, Manajemen Sumber Daya Manusia untuk Perusahaan, Edisi Kedua, Cetakan Kedua, Raja Grafindo : Jakarta.

Robbins, P.S., 2006, Perilaku Organisasi. Edisi Sepuluh. Diterjemahkan Oleh : Drs. Benyamin Molan, Erlangga : Jakarta.

Samsudin, S., 2005, Manajemen Sumber Daya Manusia, CV Pustaka Setia : Bandung.

Siagian, S.P., 2006, Manajemen Sumber Daya Manusia, Edisi Satu, Cetakan Ketiga Belas, Bumi Aksara : Jakarta.

Simamora, H., 2003, Manajemen Sumber Daya Manusia, Edisi Tiga, STIE YKPN : Jakarta.

Sugiono, 2006, Metode Penelitian Bisnis, CV. Alfabeta : Bandung.

Sulistiyani, Teguh dan Rosidah, 2003, Manajemen Sumber Daya Manusia : Konsep, Teori dan Pengembangan Dalam Konteks Organisasi Publik, Graha Ilmu : Yogyakarta. 